\title{
Patterns of Islamic Banks Financing to Increase the Number of Halal Tourism and the Local Generated Income (PAD) Growth In Indonesia
}

\author{
Fadli Muhammad \\ Program Studi Ekonomi Islam, \\ Sekolah Tinggi Ekonomi Islam SEBI, Depok \\ Email: fadli_muhammad@gmail.com
}

\begin{abstract}
This study aims to analyze the relationship of Islamic bank financing to the increase the number of halal tourists and the growth the local generated income (PAD) period 2015-2016 in 33 provinces, Indonesia. Using the research method is granger causality and panel data multiple regression with the Minitab analytical tool. This model analyzes the influence of Islamic bank financing contributions to the number of halal tours and the local generated income. The amount of Islamic banks financing in the tourism sector such as restaurant and tourism business has contributed to increase the number of halal tourists and the growth of the local generated income (PAD). The results of this study can be used for the Islamic banking industry to support capital financing for the halal industry. In previous studies only analyzed the halal tourism potential, as well as the potential of the tourism industry in general for the local generated income. However, this study discusses the contribution of Islamic bank financing to the number of halal tourism and an increase in the local generated income.
\end{abstract}

Keywords: Financing, Islamic banks, Halal tourism. 


\begin{abstract}
ABSTRAK
Penelitian ini bertujuan untuk menganalisis hubungan pembiayaan bank syariah untuk meningkatkan jumlah wisatawan halal dan pertumbuhan Pendapatan Asli Daerah (PAD) Periode 2015-2016 pada 33 provinsi di Indonesia. Menggunakan metode penelitian granger kausalitas dan panel regresi berganda dengan analisis data Minitab. Model ini menganalisis pengaruh kontribusi pembiayaan bank syariah terhadap jumlah wisatawan halal dan Pendapatan Asli Daerah (PAD). Jumlah Pembiayaan bank syariah di sektor pariwisata seperti restoran dan penginapan telah berkontribusi meningkatkan jumlah wisatawan halal dan pertumbuhan pendapatan asli daerah (PAD). Hasil studi ini dapat digunakan untuk industri perbankan syariah sebagai upaya mendukung modal pembiayaan untuk industri halal. Dalam penelitian sebelumnya hanya dianalisis tentang potensi wisata halal, serta potensi industri pariwisata secara umum untuk pendapatan lokal yang dihasilkan. Namun, penelitian ini membahas kontribusi pembiayaan bank syariah terhadap jumlah halal pariwisata dan peningkatan Pendapatan Asli Daerah (PAD) yang didapat.
\end{abstract}

Kata Kunci: Pembiayaan, Bank Syariah, Pariwisata Halal.

\title{
1. Introduction
}

The development of the tourism industry has continued to increase in recent decades and has experienced enormous potential growth. Referring to the publication report from the UN World Tourism Organization (UNWTO, 2016) that there was an increase in global tourist arrivals. This also has an impact on the Muslim tourism industry market. The world market for the Muslim tourism industry is estimated to be worth US \$ 151 billion (not including expenditures on Hajj and Umrah) in 2015. This is equivalent to $11 \%$ of global market spending which reaches US \$ 1.3 Trillion. The Muslim tourism market is also projected continue to increase, reaching US \$ 243 billion in 2021. The Muslim tourism market also has second place in the category of the country's biggest tourist source after China amounted to US \$ 168 billion and followed by the United States of US $\$ 147$ billion. As for Muslim tourists with the largest expenditure there are at least 6 countries, there was Saudi Arabia US \$ 19.2 Billion, United Arab Emirates US \$ 15.1 Billion, Qatar US \$ 11.7 Billion, Kuwait US \$ 9 Billion, Indonesia US \$ 9 Billion and Iran US $\$ 7.2$ Billion as reported by (Thomson Reuters Islamic Finance, 2016).

A very potential market share in fact has not been utilized by Indonesia. This is based on the report (Master Card \& Crescentrating, 2016) that Indonesia is still in the fourth place as a most destination for Muslim tourists. In the first position was 
occupied by Malaysia, United Arab Emirates and followed by Turkey. Even in the global report on Islamic pariwsata halal economy there is 4 main indicators namely Muslim tourists visit, development in halal tourism ecosystem, halal tourism awareness, and halal tourism sector that contribute to employment. Indonesia is also not included in 10 best countries to refer the results of publications of studies by (Thomson Reuters Islamic Finance, 2016).

In the decision to travel somewhere, there are many factors that are need to consider. Shopping Preference Theory (Sheth, 1981) reveals that one's choice falls when there is a match between demand and supply. Tourism needs in general must also be fulfilled such as favorite tourist objects, weather conditions, accommodation, tourism activities, shopping spots, food, transportation and living cost (Paingpis Sriprasert, 2014). As stated in the study by Din (1989), the requisite of Muslim tourists include the development of Islamic lifestyles during holidays such as halal food, support tools in daily worship such as prayer and cleanliness of the residence. Where it must be provided in the Muslim travel in accordance with the values of Islamic teachings and does not violate its provisions (Jafari \& Scott, 2014).

Generally, halal tourism consists of several components such as actors, tourist attractions and tourism products (Din, 1989). Tourist products are also an important component in halal tourism needs such as attractive tourist attractions, Islamic art and heritage and Islamic specialties (halal food) (Mohamed Battour, 2015). Indonesia itself has carried out the development of halal tourism by developing infrastructure including sharia hotels (Kemenpar, 2015). Sriprasert, Chainin, \& Rahman (2014), states that the majority of Muslim tourists use hotel accommodation or homestay when making travel visits. Therefore, it is very logical if Islamic hotels will develop in line with the development of halal tourism. This is possible, because Muslim tourists certainly need an accommodation in accordance with sharia (Poria, 2003). Din (1989), states that sharia compliance is a special need for Muslim tourists who are strongly influenced by Islamic teachings. In 2016, Indonesia has totalled 101 sharia hotels, where this number is far from the expected amout. The ideal number of sharia hotels is 273 sharia hotels with 8,880 rooms to be able to accommodate the needs and desires of Muslim tourists for sharia hotels (Sofyan, 2016). So that sharia hotels need to be developed intensively.

Lack of industries engaged in halal tourism is alleged as a factor of halal tourism unoptimal growth. Indonesia's potential for halal tourists has not been explored well. According to Battour (2015), that the success of halal tourism development must be accompanied by the adoption of Islamic thought and principles in all aspects of tourism activities, so that they can see the opportunities. Why is this happen? Because of the opportunity for tourism industrial growth has not been fully supported by the banking sector, especially Islamic banking. According to research conducted in Lombok (Sidharta, 2017) 
there are several factors that cause the role of Islamic banking in supporting halal tourism is still not optimal yet such as lack of education, socialization, appropriate marketing and innovation. Optimization of halal tourism support also should be supported by the local government. As with the study (Sulistiana, 2016) that there is a direct influence between the number of hotels, the number of tourism objects and the number of workers in Lombok with the increase in local revenue (PAD) during 2009-2015. Same as in the area of West Sumatra in the study (Fitri, Ansofino, \& Desi Areva, 2014) which states that there is an influence of improvement in the tourism sector such as the purchase of handicrafts or souvenirs by tourists on locally-generated revenue. This is in line with research conducted by (Jamal \& Lee, 2013) that tourism can affect several aspects, namely in terms of economic, social, environmental and even political.

So that the purpose of this study is primarily aimed at this and specifically try: (1) Identifying the pattern of relationships in the form of contributions and the influence of growth in islamic bank financing, religious tourism and locallygenerated revenues (PAD) 33 provinces in Indonesia in 2015-2016 (2) Analyzing the growth response of Islamic bank financing to religious tourism and the growth of locally-generated revenue in 33 provinces in Indonesia throughout 2015-2016.

\section{Literature Review}

According to Din (1989), in Islam \& Tourism, the definition of halal tourism as a way to appreciate the greatness of God's creation, so it is stated that halal tourism comes from the motivation of Islam. In contrast opinion from Kamarudin (2012), in Muslim Tourist Typology In Malaysia: Perspective and Challenge, the concept of halal tourism can also be considered as worship and preaching where tourists travel from one place to another to get blessings from God and avoid mistakes during their trip. This is almost the same as the opinion of Laderlah (2011), in A Study on Islamic Tourism a Malaysia Experience. Halal tourism also includes the happiness of the world and the hereafter and its impact can strengthen human relations to their God. Where this is indirectly tourists who engage in halal tourism must be motivated to get pleasure and blessings from God.

Referring to the fatwa issued by the National Sharia Council of the Indonesian Ulema Council (DSN MUI) (2016), halal tourism is a travel activity carried out by a person or group of people by visiting certain places for recreational purposes, personal development or learning the unique tourist attractions within a temporary period and in accordance with sharia principles. However, according to OIC (2015), International Tourism in the OIC Countries: Prospects and Challenges. Ankara Turkey: The Statistical, Economic and Social Research and Training genre for Islamic Countries. Halal tourism generally targets people who believe in Islam even though there are also universal attractions such as fair prices, peace, security, a friendly and hygienic environment but generally must uphold the principles of Islam. 
According to Duman (2011), in the Value of Islamic Tourism: Perspective from the turkish experience. Halal tourism is one of new segment to meet the demand based on the motivation of tourists to choose an Islamic lifestyle during the holidays. In line with the opinion of Paingpis Sriprasert (2014), Understanding Behavior and Needs of Halal Tourism in Andaman Gulf of Thailand: A Case fo Asian Muslim. This study discusses the typology of Muslim tourists and their needs. Globally, this need must be introduced in the form of information so that it becomes an attraction, moreover this is a special needs. So we need industries that are engaged in tourism such as the halal food industry, travel agents that facilitate halal tourism and lodging that provides playgrounds, and places of worship for Muslim needs.

Indonesia's potential for halal tourists has not been explored well, according to Battour (2015). Halal tourism: Concepts, practices, challenges and futures. Encouragement for the development of tourism products is also an important component in halal tourism needs such as attractive tourist attractions, Islamic arts and heritage and Islamic specialties (halal). Policies to encourage the growth of the tourism industry must be supported by bank financing, this has been often discussed in international forums.

Due to this large influence in the economy as stated by Hawkins \& Mann, (2007), the World Bank's Role in Tourism Development. In poor and developing countries that have natural tourism potential, it is very possible for the development of the tourism industry to expand employment, and increase the community income and also the State. Even the world bank has a MIGA division (a world bank institution to monitor risk mitigation for each project) has made the tourism industry among their main focus. This was stated in the research (Perić, Mujačević, \& Šimunić, 2010). In this study also stated that the travel and tourism industry produces 234 million direct and indirect jobs worldwide, contributes more than 10 percent of global GDP, and redound for one-third of all international trade in services. International visitors spend nearly $\$ 900$ billion on goods and services each year, with inflows related to tourism often being the main source of foreign exchange in many developing countries. Tourists spend more than $\$ 200$ billion annually in emerging markets. tourism: statistics show that 1 in 12 jobs globally is related to travel and tourism.

In the context of halal tourism, the development and growth of halal tourism should be driven by the Islamic finance industry. As stated Muhamed, Ramli, Aziz, \& Yaakub (2014), "Integrating Islamic Financing and Halal Industry: A Survey on Current Practices of the Selected Malaysian Authority Bodies”. In the context of the gap between the halal industry (including halal tourism) and industrial financing in Malaysia, this study proposes the existence of appropriate and sustainable integration between the Islamic finance industry and the halal industry. In tourism sector financing there must be examples and empirical facts because this sector is more containing service sector. As presented by Dar \& 
Mehta (2014), in their research an Assessment of the Role of Financial Institutions in Tourism Development of Kashmir: A Demand Side of Market, Financing for tourism must be in accordance with its sectors, it cannot be equated with each other, so many factors must be analyzed. Similarly, in terms of financing to open a new business or branch business, it must be selective in this financing. This is accordingly conveyed by Sterren (2008), in his research Financial Markets, Microfinance and Tourism in Developing Countries. That the right financing to be developed in developing countries is microfinance institutions. This is because of the tourism industry development in an area will affect to the development of small and medium micro businesses in there so that financing to develop it is strongly needed.

\section{Research Method}

The study uses data on the number of religious tourists, the amount of Islamic bank financing and the total locally-generated Revenue (PAD) of 33 provinces throughout Indonesia during the 2015-2016 period. The variables used are the number of religious tourists sourced from the data of the tourism ministry as a representation of halal tourists. Furthermore, the financing of Islamic banks in sectors related to tourism such as restaurants and hotels as a representation of Islamic banks financing the halal tourism sector. The last is local revenue as a representation of the economic growth of each province for halal tourism.

The research model that used in this study was to assess the contribution of Islamic bank financing to the increase in the number of tourists and local revenue. In this study using multiple linear regression with Minitab analysis tools. But before doing data processing, there are stages that must be fulfilled, are classic assumptions. The classic assumptions include the normality of multiple linear regression, multicollinearity and autocorrelation.

\section{Result and Discussion}

Referring to the results of normality, as in the normal probability plot it can be concluded that the residuals are normally distributed because the majority of the picture still follows a straight line. While the histogram table is also stated to be normally distributed because the shape resembles a bell facing upwards. The symptom of heteroskedasity can be determined by a scatter diagram that is between the prediction variable and the residual variable.

As if to detect the symptoms of multicolinerity can be seen from the VIF value. From the research conducted, shows that the VIF value and two variables are 1.43 so that there can be no symptoms of multicolinerity. Where as the regression output with the Minitab analysis tool Multiple Regression Model, shows as follow: 
Tabel 1.1

Model Summary

\begin{tabular}{cccc}
\hline $\mathbf{S}$ & $\mathbf{R}-\mathbf{s q}$ & R-sq(adj) & R-sq(pred) \\
\hline 127.516 & $92.26 \%$ & $92.01 \%$ & $88.20 \%$ \\
\hline
\end{tabular}

Tabel 1.2

Coefficients

\begin{tabular}{cccccc}
\hline $\begin{array}{l}\text { Term } \\
\text { Constant }\end{array}$ & $\begin{array}{c}\text { Coef } \\
-18.5\end{array}$ & $\begin{array}{c}\text { SE Coef } \\
18.4\end{array}$ & $\begin{array}{c}\text { V- } \\
-1.00\end{array}$ & $\begin{array}{c}\text { P-Value } \\
0.319\end{array}$ & VIF \\
\hline $\mathrm{W}$ & -0.000070 & 0.000018 & -3.82 & 0.000 & 1.43 \\
\hline \multirow{2}{*}{ PAD } & 0.000000 & 0.000000 & 24.76 & 0.000 & 1.43 \\
\hline
\end{tabular}

Table 1.3

Regression Equation

$\mathrm{PBS}=-18.5-0.000070 \mathrm{~W}+0.000000 \mathrm{PAD}$

Standard Error of Estimate (SEE) is used to determine whether the regression model is declared valid as a prediction model. The value can be seen on the minitab, value of $S$ at the output of session 1 where in this test is 127,516 . This SEE value compares with the standard deviation of the dependent variable or Y of 447,489.A valid model is declared as a predictive model if the SEE value $<$ standard deviation value of the dependent variable.

On the other hand, F test on regression serve as a simultaneous test, which is to determine whether all independent variables simultaneously have a significant effect on the dependent variable can be seen from the $F$ test value. It was concluded that there was an influence if the $\mathrm{P}$ value was less than the critical research limit or alpha. For example in this test, see session 1 output, the Regression $\mathrm{P}$ value in Analysis of Variance is 0,000 means $<0.05$, it can be concluded that simultaneously the independent variables have a significant effect on the dependent variable. So it can be interpreted that there are influences of Islamic bank financing on increasing the number of halal tourists and local revenue.

The Partial $\mathrm{T}$ is used for determine whether the independent variables in the regression model have individual influence on the dependent variable by observing the existence of other variables in the model. The partial $t$ value can be seen through the $t$ value at output 2 above. It is stated that there is a partial effect 
if the $\mathrm{p}$ value $(\mathrm{P})$ is less than the critical research limit or alpha. Above all independent variables $p$ value of partial $t$ value $<0.05$, so that there is an individual influence on $\mathrm{Y}$ by observing other variables. So that it can be concluded that there are influences between the variables of financing Islamic banks, halal tourists and locally-generated revenue.

In this case, it can be directly seen through the regression equation is at the output of session 1, where the result: PBS $=-18.5-0.000070 \mathrm{~W}+0.000000$ PAD. Therefore the value of negative intercepts can be ignored because the assumptions that have been fulfilled previously do not affect the model. So, the equation above can be concluded that Square is also called the Multiple Determination Coefficient. R Square in Minitab is indicated by the value of R-Sq where the value can be seen in output session 2 that is equal to $92 \%$ which means that $\mathrm{Y}$ variable can be explained by a group of independent variables x1, x2 simultaneously or in unison by $92 \%$ while the rest $(100 \%-92 \%=8 \%)$ is explained by other variables outside the model that are not examined. So that indicates that the financing of Islamic banks contributes to the increase in the number of halal tourists and locally-generated revenue.

\section{Tabel 1.4 \\ Granger Causality}

Pairwise Granger Causality Tests
Date: 06/05/18 Time: 07:27
Sample: 20152016
Lags: 2

Based on multiple regression analysis (data panel) above, it is known that the Islamic banks financing, especially those including the tourism sector (restaurants and lodging businesses and other services) have an influence on the number of halal tourists and an increase in local revenue (locally-generated revenue). This makes an indicator that the financing of Islamic banks in the tourism industry sector becomes one of the factors determining the increase in halal tourists and increasing the growth of locally-generated revenue in the province.

As for the variant contribution in the influence of Islamic bank financing on the growth of the number of Muslim tourists and an increase in local revenue by 
$92 \%$ and $8 \%$ due to other factors. Likewise on the results of research through granger causality that there is an influence of the number of halal tourists on increasing financing of Islamic banks and local revenue. As well as the influence of Islamic bank financing on local revenue. So it can be concluded that this research can be useful for the Islamic finance industry in order to increase financing, especially capital financing in the halal tourism sector in each province. And the increasing trend of halal tourism specialization must continue to be echoed for regulators such improving tourist facilities, and regulating the tourism industry, especially small and medium enterprises. Sustainable promotion for every potential tourism area is also important. Because it refers to the results of this study that when an increase in the number of halal tourists will cause an increase in local revenue.

In the future, this evaluation is also a matter of consideration for local governments to continue optimizing the halal tourism industry. Although it was realized that of course there were still many shortcomings in this study so that the advanced research was highly anticipated to complete this study. The same is true for the optimization of the halal industry in Indonesia so that it can become the main focus of Islamic bank financing and for stakeholders to develop the halal tourism industry so as it is worthwhile for the propagation of Islamic economics in Indonesia in the future.

\section{Conclusion}

If it refers to the results of the process, then we can conclude that those who have a causality relationship are those that have a probability value smaller than alpha 0.05 . So that later $h^{0}$ will be rejected. Therefore a variable will affect other variables. Then it can be concluded as follows: first, an improvement of Islamic bank financing (0.00) affects the local generated income for some province in Indonesia. Second, an increase in the number of religious or halal tourists $(0.00)$ affects the local generated income. Third, an increase in the number of religious or halal tourists $(0,00)$ influences the outlay of Islamic banks.

\section{Reference}

Dar, A. A., \& Mehta, S. K. (2014). Assessment of the Role of Financial Institutions in Tourism Development of Kashmir: A Field Study from Demand Side of Market. Journal of Kashmir for Tourism and Catering Technology, 14-24.

Din, K. H. (1989). Islam \& Tourism. Annals of Tourism Research, 542-563.

DSN MUI, (2016). Pedoman Penyelenggaraan Pariwisata Berdasarkan Prinsip Syariah. Fatwa MUI (hal. 1-9). Jakarta: DSN MUI.

Duman, T. (2011). The Value of Islamic Tourism: Perspective from the Turkish Experience. Islam and Civilisational renewal, 718-738. 
Fitri, D., Ansofino, \& Desi Areva. (2014). Tourism Sector Effect on Local Revenue (PAD) in the district of Pesisir Selatan. Pendidikan EKonomi dan Bisnis STKIP PGRI Sumatera Barat, 2-15.

Hawkins, D. E., \& Mann, S. (2007). The World Bank's Role in Tourism Development. Annals of Tourism Research, Vol. 34, No. 2, 348-363.

Jafari, J., \& Scott, N. (2014). Muslim world and its tourisms. Annals of Tourism Research, 1-19.

Jamal, \& Lee, J. H. (2013). Integrating Micro and Macro Approaches to Tourist Motivations: Toward an Interdisciplinary Theory. Tourism Analysis, 47-59.

Kadhim, F. A., Abdullah, T. F., \& Mahir, F. A. (2016). Effects of Marketing mix on customer satisfication: empirical study on tourism industry in Malaysia. International Journal of Applied Research, 357-360.

Kamarudin, L. M. (2012). Muslim Tourists' Typology In Malaysia: Perspectives And Cahllenges. Tourism and Hospitality International Conference, 1-8.

Kemenpar. (2015). Laporan Akhir Kajian Pengembangan Pariwisata Syariah. Jakarta: Kementrian Pariwisata.

Laderlah all, S. A. (2011). A Study on Islamic Tourism A Malaysia Experience. Internasional COnference on Humanities, Historical and Social Science, 1-6.

Master Card \& Crescentrating. (2016). Global Muslim Travel Index 2016. Singapore: Master Card Asia Pasific \& Crescentrating.

Mohamed Battour, M. N. (2015). Halal tourism: Concepts, practises, challenges and future. Tourism Management Perspectives, 150-154.

Muhamed, N. A., Ramli, N. M., Aziz, S. A., \& Yaakub, N. A. (2014). Integrating Islamic Financing and Halal Industry: A Survey on Current Practices of the Selected Malaysian Authority Bodies. Asian Social Science; Vol. 10, No. 17, $1-7$.

OIC, (2015). International Tourism in the OIC Countries: Prospects and Challenges. Ankara Turkey: The Statistical, Economic and Social Research and Training Cenre for Islamic Countries.

Paingpis Sriprasert, O. C. (2014). Understanding Behaviour and Needs of Halal Tourism in ANdaman Gulf of Thailand: A Case fo Asian muslim. Journal of Advanced Management Science, 216-219.

PERIĆ, J., MUJAČEVIĆ, E., \& ŠIMUNIĆ, M. (2010). International financial institution investments in tourism and hospitality. Journal of International Business and Cultural Studies, 1-17.

Poria, Y. B. (2003). The Core of Heritage Tourism. . Annals of Tourism Research, Vol. 30, No. 1, 238-254.

Sheth, J. N. (1981). An Integrative Theory of Patronage Preference. Champaign, Illinois, Amerika Serikat: University of Illinois, Urbana-Champaign.

Sidharta, R. B. (2017). Optimalisasi Peran Perbankan Syariah Dalam Mendukung Wisata Halal. Jurnal Distribusi Manajemen dan Bisnis, 1-14.

Sriprasert, Chainin, \& Rahman. (2014). Understanding Behavior and Needs of Halal Tourism in Andaman Gulf of Thailand: A Case of Asian Muslim. Journal of Advanced Management Science, 2 (3), 216-219.

Sterren, J. v. (2008). Financial Markets, Microfinance and Tourism in Developing Countries. Journal International economic NHTV Breda University of Applied Sciences, Breda, the Netherlands, 35-44. 
Sulistiana. (2016). Analisis Pengaruh Sektor Pariwisata Terhadap Tingkat Penyerapan Tenaga Kerja Dan Pendapatan Asli Daerah Di Lombok 20092015. Jurnal Manajemen dan Bisnis, 1-20.

Thomson Reuters Islamic Finance. (2016). State of Global Islamic Economy Report. New York, USA: Thomson Reuters Islamic Finance \& Dinar Standard.

UNWTO. (2016). Tourism Highlight. Madrid: World Tourism Organization. 